\title{
Pattern of Skin Diseases in Ebonyi State University Teaching Hospital
}

\section{Okoh NU1*, Nnaji $\mathrm{TO}^{2}$ and Okoro $\mathrm{AN}^{3}$}

${ }^{1}$ Consultant Physician, Department of Internal Medicine, Federal Teaching Hospital Abakaliki, Ebonyi state, Nigeria

${ }^{2}$ Consultant Physician, Department of Internal Medicine, Federal Teaching Hospital,

\section{Research Article}

Volume 2 Issue 1

Received Date: May 17, 2018

Published Date: June 27, 2018 Abakaliki, Ebonyi state, Nigeria

3Professor of Medicine/Consultant Physician, Department of Internal Medicine, Ebonyi State University, Abakaliki, Ebonyi state, Nigeria

*Corresponding author: Dr Okoh, NU, Consultant Physician, Department of Internal Medicine, Federal Teaching Hospital Abakaliki, Ebonyi state, Nigeria, Email: nnennaogbonna@yahoo.com

\section{Abstract}

We report the pattern of skin diseases seen in the dermatology clinic of the Ebonyi State University Teaching Hospital, Abakaliki from November 1998 to December 2012. Four thousand and six (4006) new patients were seen during the study period. There were more females than males with a female/male ratio of $1.42: 1$. Infectious diseases accounted for $30.8 \%$ of all the skin disorders. This is consistent with early studies carried out in Nigeria and some other parts of Africa. Other top ranking skin diseases observed in decreasing order of frequencies include eczematous disorders (27.7\%), urticaria/pruritus (7.7\%), pilosebaceous disorders (5.4\%), pigmentary disorders (5.1\%) and papulosquamous disorders (5.0\%). HIV related skin diseases accounted for $2.7 \%$ of disorders seen. The current pattern of diseases observed seemed to follow similar pattern observed in earlier studies and in contrast to recent studies. Infectious disorders ranked highest with eczematous disorders closely following.

Keywords: Epidemiology; Africa; Diagnosis; Skin

\section{Introduction}

Skin diseases are important and are a common cause of ill health in Africa [1]. In Africa, poor nutrition, inadequate portable water supply and poor environmental sanitation all add to the burden of disease [2]. The distribution of skin diseases varies from one country to another and between regions in the same country. There are various reports on the pattern of skin diseases in different areas of Nigeria with some observed differences [3-7]. With this study, we hope to identify the common skin disorders in our environment as this will assist in proper planning and management of these disorders.

\section{Materials and Methods}

This is a retrospective review of skin diseases in new patients presenting to the skin clinic of the Ebonyi State University Teaching Hospital in Abakaliki, Ebonyi state 


\section{Epidemiology international journal}

in South Eastern Nigeria between November 1998 and December 2012. Data was compared with findings from other geo-political zones. Ebonyi state was created in 1996 from old Abakaliki division of Enugu state and old Afikpo division of Abia state. It has a land mass of 5935 $\mathrm{km}^{2}$ sharing boundaries with Enugu on the West, Cross River in the East, Abia in the South-East and Benue in the North. The state has 13 local government areas (LGAs). It has an estimated population of 4.3 million. About $75 \%$ of the population are rural dwellers with farming as the predominant occupation [8]. The hospital, being a tertiary hospital receives referral from all hospitals in the state and neighbouring states.

The patients age, gender and skin disease diagnosis were extracted from the medical records. The diagnosis in most instances was clinical and supplemented in few cases by histology. Other tests done were skin scraping for mycology tests, skin snip for microfilaria and slit skin smear for M.leprae.

The Statistical Package for Social Sciences (SPSS) version 16 was used for data entry and analysis.

\section{Ethical Considerations}

This study was carried out in accordance with the Code of Ethics of the World Medical Association (Declaration of Helsinki).

\section{Results}

Four thousand and six (4006) new patients attended the skin clinic within the review period. Pure dermatological consultations accounted for $76.9 \%$ (3080) of the patients, while HIV and HIV related skin diseases accounted for $23.1 \%$ (926) of the patients. About 95(3.1\%) had more than one dermatological diagnosis. There were more females $2353(58.7 \%)$ than males $1653(41.3 \%)$, with a female/male ratio of 1.42:1.

Nine hundred and fifty nine (23.9\%) were less than 16 years while $3047(76.1 \%)$ were more than 16 years. The ages of the patients ranged from 1 week to 90 years. The mean \pm S.D of age was $27.65 \pm 13.96$ years. Figure 1 below shows the age and sex distribution of all the new patients seen over this time frame, 1998- 2012.

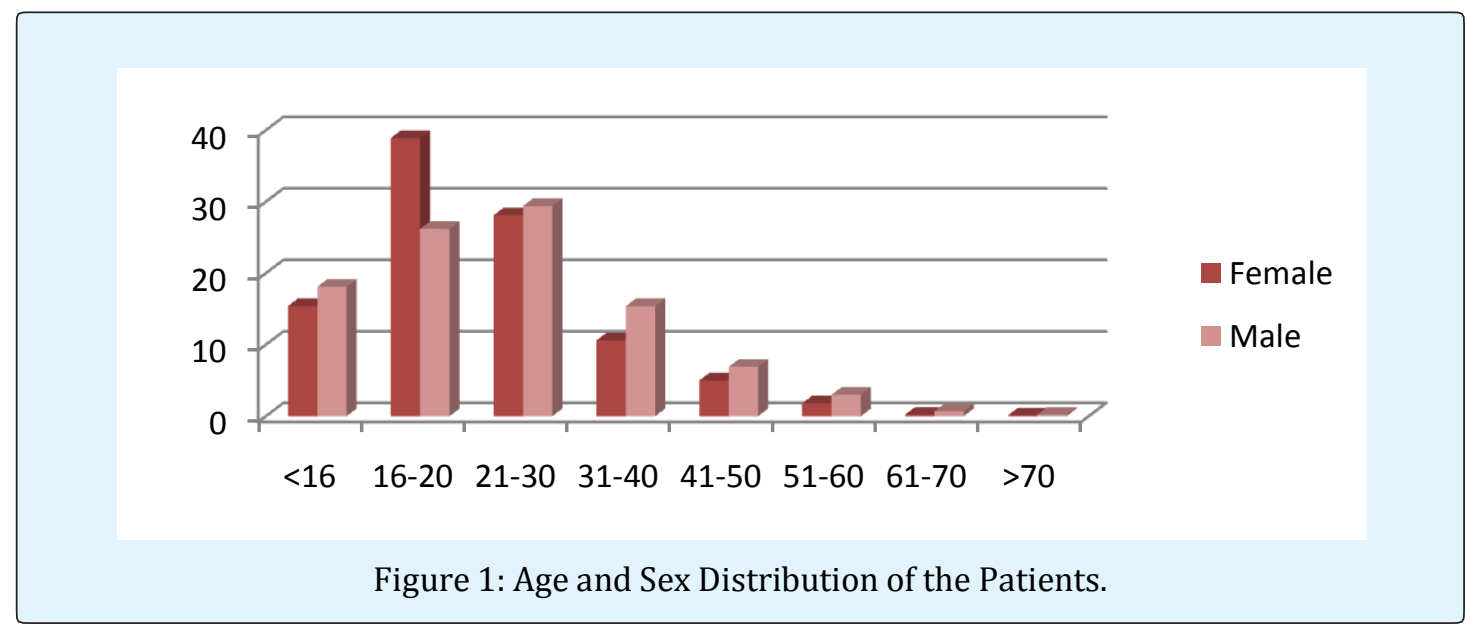

\begin{tabular}{|c|c|c|}
\hline Skin diseases & Frequency & \% \\
\hline Infections/infestations & 980 & 30.8 \\
\hline Dermatitis & 883 & 27.7 \\
\hline Urticaria/pruritus & 245 & 7.7 \\
\hline Pilosebaceous disorders & 173 & 5.4 \\
\hline Pigmentary disorders & 162 & 5.1 \\
\hline Papulosquamous disorders & 160 & 5.0 \\
\hline Adverse drug reaction & 99 & 3.1 \\
\hline Disorders of keratinization & 99 & 3.1 \\
\hline HIV related skin diseases & 85 & 2.7 \\
\hline Fibrous tumours of the skin & 76 & 2.4 \\
\hline Neurocutaneous disorders & 32 & 1.0 \\
\hline Hair disorders & 31 & 1.0 \\
\hline Connective tissue disease & 19 & 0.6 \\
\hline Benign neoplastic disorders & 17 & 0.5 \\
\hline Bullous disorders & 17 & 0.5 \\
\hline Cutaneous malignancies & 13 & 0.4 \\
\hline
\end{tabular}




\section{Epidemiology international journal}

\begin{tabular}{|c|c|c|}
\hline Lymphoedema & 12 & 0.4 \\
\hline Psychiatric disorders & 6 & 0.2 \\
\hline Miscellaneous & 77 & 2.4 \\
\hline Total & $\mathbf{3 1 8 6}$ & $\mathbf{1 0 0}$ \\
\hline
\end{tabular}

Table 1: Main Disease Groups.

\begin{tabular}{|c|c|c|c|}
\hline $\begin{array}{c}\text { Infections/ } \\
\text { infestations }\end{array}$ & Frequency & \%Group & \%Total \\
\hline Fungal & 460 & 46.9 & 14.4 \\
\hline Bacterial & 288 & 29.4 & 9.0 \\
\hline Viral & 134 & 13.7 & 4.2 \\
\hline Parasitic & 98 & 10 & 3.1 \\
\hline Total & $\mathbf{9 8 0}$ & $\mathbf{1 0 0}$ & $\mathbf{3 0 . 8}$ \\
\hline
\end{tabular}

Table 2: Infective Disorders.
Table 1 is a summary of the different categories of skin disorders that were seen in the review period. From this, it was observed that cutaneous infections and infestations had the highest prevalence of $30.8 \%$ followed by dermatitis which was $27.7 \%$. Table 2 shows a breakdown of the infective skin diseases with fungal infections ranking highest with $46.9 \%$ of infective causes while bacterial, viral infections and parasitic infestations were $29.4 \%, 13.7 \%$, and $10 \%$ respectively.

\begin{tabular}{|c|c|c|c|}
\hline & Frequency & \%Group & \%Total \\
\hline \multicolumn{4}{|l|}{ Dermatitis } \\
\hline Nonspecific-chronic dermatitis & 419 & 47.4 & 13.1 \\
\hline Atopic dermatitis & 127 & 14.4 & 4.0 \\
\hline Seborrheic dermatitis & 111 & 12.6 & 3.5 \\
\hline Allergic contact dermatitis & 80 & 9.1 & 2.5 \\
\hline Lichen simplex chronicus/prurigonodularis & 49 & 5.5 & 1.5 \\
\hline $\begin{array}{l}\text { Pompholyx } \\
\end{array}$ & 29 & 3.2 & 0.9 \\
\hline Nummular dermatitis & 28 & 3.2 & 0.9 \\
\hline Exfoliative dermatitis & 23 & 2.6 & 0.7 \\
\hline Stasis dermatitis & 5 & 0.6 & 0.2 \\
\hline Breast eczema & 5 & 0.6 & 0.2 \\
\hline Photodermatitis & 4 & 0.4 & 0.1 \\
\hline Irritant contact dermatitis & 3 & 0.3 & 0.09 \\
\hline Group total & 883 & 100 & 27.7 \\
\hline Hidradenitis suppurativa & 2 & 1.15 & 0.05 \\
\hline Steatocystoma multiplex & 2 & 1.15 & 0.05 \\
\hline Group total & 173 & 100 & 5.4 \\
\hline \multicolumn{4}{|l|}{ Pigmentary disorders } \\
\hline Vitiligo & 99 & 61.1 & 3.1 \\
\hline Albinism & 15 & 9.3 & 0.5 \\
\hline Postinflammatory hyperpigmentation & 15 & 9.3 & 0.5 \\
\hline Hypermelanosis & 14 & 8.6 & 0.4 \\
\hline Postinflammatory hypopigmentation & 9 & 5.6 & 0.3 \\
\hline $\begin{array}{c}\text { Pellagra } \\
\end{array}$ & 6 & 3.7 & 0.2 \\
\hline Idiopathic guttatehypomelanosis & 2 & 1.2 & 0.06 \\
\hline Chloasma & 1 & 0.6 & 0.03 \\
\hline Freckles & 1 & 0.6 & 0.03 \\
\hline Group total & 162 & 100 & 5.10 \\
\hline \multicolumn{4}{|l|}{ Papulosquamous disorders } \\
\hline Pityriasis rosea & 75 & 46.9 & 2.4 \\
\hline Lichen planus & 50 & 31.3 & 1.6 \\
\hline Psoriasis & 19 & 11.9 & 0.6 \\
\hline Lichen nitidus & 5 & 3.1 & 0.12 \\
\hline Lichen striatus & 5 & 3.1 & 0.12 \\
\hline PLEVC & 4 & 2.5 & 0.1 \\
\hline Pityriasis rubra pilaris & 1 & 0.6 & 0.03 \\
\hline
\end{tabular}


Epidemiology international journal

\begin{tabular}{|c|c|c|c|}
\hline PLEVA & 1 & 0.6 & 0.03 \\
\hline Group total & 160 & 100 & 5.0 \\
\hline \multicolumn{4}{|l|}{ Viral Infections } \\
\hline Viral warts & 48 & 35.8 & 1.5 \\
\hline Herpes simplex & 26 & 19.4 & 0.8 \\
\hline Herpes zoster & 25 & 18.7 & 0.8 \\
\hline Molluscum contagiosum & 16 & 11.9 & 0.5 \\
\hline Varicella & 11 & 8.2 & 0.4 \\
\hline Viral exanthem & 7 & 5.2 & 0.2 \\
\hline Miscellaneous & 1 & 0.8 & 0.03 \\
\hline Group total & 134 & 100 & 4.2 \\
\hline \multicolumn{4}{|l|}{ Adverse drug eruption } \\
\hline FDE & 74 & 74.7 & 2.3 \\
\hline Nonspecific eruption & 15 & 15.3 & 0.5 \\
\hline Acneiform eruption & 3 & 3.0 & 0.09 \\
\hline SJS & 2 & 2.0 & 0.05 \\
\hline Hypopigmentation & 2 & 2.0 & 0.05 \\
\hline Striae & 1 & 1.0 & 0.03 \\
\hline Hyperpigmentation & 1 & 1.0 & 0.03 \\
\hline Mazzoti reaction & 1 & 1.0 & 0.03 \\
\hline Group total & 99 & 100 & 3.1 \\
\hline \multicolumn{4}{|l|}{ Disorders of keratinization } \\
\hline Follicular hyperkeratosis & 52 & 52.5 & 1.6 \\
\hline Phrynoderma & 31 & 31.3 & 1.0 \\
\hline Callosities/corns & 8 & 8.1 & 0.3 \\
\hline Ichthyosis & 7 & 7.1 & 0.2 \\
\hline Tylosis & 1 & 1.0 & 0.03 \\
\hline Group total & 99 & 100 & 3.1 \\
\hline \multicolumn{4}{|l|}{ Parasitic infestations } \\
\hline Onchodermatitis & 49 & 50 & 1.5 \\
\hline Scabies & 39 & 39.9 & 1.2 \\
\hline Cutaneous leishmaniasis & 2 & 2.0 & 0.05 \\
\hline Tumbu fly & 1 & 1.0 & 0.03 \\
\hline Cutaneous larva migrans & 1 & 1.0 & 0.03 \\
\hline Others & 6 & 6.1 & 0.2 \\
\hline Group total & 98 & 100 & 3.1 \\
\hline \multicolumn{4}{|l|}{ Nail disorders } \\
\hline Acute paronychia & 1 & 1.1 & 0.03 \\
\hline Chronic/candida paronychia & 26 & 29.6 & 0.82 \\
\hline Tinea unguium/Onychomycosis & 61 & 69.3 & 1.9 \\
\hline Group total & 88 & 100 & 2.8 \\
\hline \multicolumn{4}{|l|}{ HIV related skin diseases } \\
\hline Papular pruritic eruption & 18 & 21.2 & 0.6 \\
\hline Herpes zoster & 16 & 18.8 & 0.5 \\
\hline Kaposi sarcoma & 11 & 12.9 & 0.4 \\
\hline Bacterial infections & 10 & 11.8 & 0.3 \\
\hline Dermatophytes & 7 & 8.2 & 0.2 \\
\hline Seborrheic dermatitis & 7 & 8.2 & 0.2 \\
\hline Chronic paronychia & 4 & 4.7 & 0.12 \\
\hline Herpes simplex & 3 & 3.5 & 0.09 \\
\hline Viral warts & 3 & 3.5 & 0.09 \\
\hline Pruritus & 2 & 2.4 & 0.05 \\
\hline Scabies & 2 & 2.4 & 0.05 \\
\hline Varicella & 1 & 1.2 & 0.03 \\
\hline
\end{tabular}


Epidemiology international journal

\begin{tabular}{|c|c|c|c|}
\hline Drug eruption & 1 & 1.2 & 0.03 \\
\hline Group total & 85 & 100 & 2.7 \\
\hline \multicolumn{4}{|l|}{ Fibrous tumours of skin } \\
\hline Keloids & 43 & 56.6 & 1.4 \\
\hline Naevus & 16 & 21.1 & 0.5 \\
\hline Actinic keratosis & 6 & 7.9 & 0.2 \\
\hline Dermoid cyst & 4 & 5.3 & 0.12 \\
\hline Pyogenic granuloma & 3 & 3.9 & 0.09 \\
\hline Hypertrophic scars & 2 & 2.6 & 0.05 \\
\hline Sebaceous cyst & 2 & 2.6 & 0.05 \\
\hline Group total & 76 & 100 & 2.4 \\
\hline \multicolumn{4}{|l|}{ Neurocutaneous disorders } \\
\hline Neurofibromatosis & 32 & 100 & 1.0 \\
\hline Group total & 32 & 100 & 1.0 \\
\hline \multicolumn{4}{|l|}{ Hair disorders } \\
\hline Alopecia areata & 20 & 64.5 & 0.63 \\
\hline Acne keloidalisnuchae & 4 & 12.9 & 0.12 \\
\hline Alopecia & 4 & 12.9 & 0.12 \\
\hline Scarring alopecia & 3 & 9.7 & 0.09 \\
\hline Group total & 31 & 100 & 1.0 \\
\hline \multicolumn{4}{|l|}{ Connective tissue diseases } \\
\hline DLE & 12 & 63.2 & 0.4 \\
\hline Scleroderma & 4 & 21.0 & 0.12 \\
\hline Mixed connective tissue disease & 3 & 15.8 & 0.09 \\
\hline Group total & 19 & 100 & 0.6 \\
\hline \multicolumn{4}{|l|}{ Benign neoplastic disorders } \\
\hline Dermatosispapulosanigra & 15 & 88.2 & 0.47 \\
\hline Syringoma & 2 & 11.8 & 0.05 \\
\hline Group total & 17 & 100 & 0.5 \\
\hline \multicolumn{4}{|l|}{ Bullous disorders } \\
\hline Erythema multiforme & 9 & 52.9 & 0.3 \\
\hline Dermatitis herpetiformis & 4 & 23.5 & 0.12 \\
\hline Pemphigus vulgaris & 3 & 17.6 & 0.09 \\
\hline Pemphigus foliaceus & 1 & 5.9 & 0.03 \\
\hline Group total & 17 & 100 & 0.5 \\
\hline \multicolumn{4}{|l|}{ Cutaneous Malignancies } \\
\hline Endemic Kaposi sarcoma & 4 & 30.8 & 0.12 \\
\hline SCC & 4 & 30.8 & 0.12 \\
\hline $\mathrm{BCC}$ & 2 & 15.4 & 0.05 \\
\hline Malignant melanoma & 2 & 15.4 & 0.05 \\
\hline Basal cell epithelioma & 1 & 7.7 & 0.03 \\
\hline Group total & 13 & 100 & 0.4 \\
\hline \multicolumn{4}{|l|}{ Lymphoedema } \\
\hline Lymphoedema & 12 & 100 & 0.4 \\
\hline Group total & 12 & 100 & 0.4 \\
\hline \multicolumn{4}{|l|}{ Psychiatric disorders } \\
\hline Trichotillomania & 2 & 33.3 & 0.05 \\
\hline Formication & 2 & 33.3 & 0.05 \\
\hline Dermatitis artefacta & 1 & 16.7 & 0.03 \\
\hline Venerophobia & 1 & 16.7 & 0.03 \\
\hline Group total & 6 & 100 & 0.2 \\
\hline Miscellaneous & 77 & 100 & 2.4 \\
\hline
\end{tabular}

Table 3: Is the breakdown of the specific conditions. 


\begin{tabular}{|c|c|}
\hline Miscellaneous skin disorders: & Frequency \\
\hline Xanthelasma palpebrarum & 8 \\
\hline Haemangioma & 8 \\
\hline Miliaria & 6 \\
\hline Granuloma telangiectasia & 6 \\
\hline Post bleaching syndrome & 6 \\
\hline Striae distensae & 5 \\
\hline Granuloma annulare & 5 \\
\hline Panniculitis & 3 \\
\hline Erythema nodosum & 3 \\
\hline Xanthoma & 2 \\
\hline Hyperhidrosis & 2 \\
\hline Calcinosis cutis & 2 \\
\hline Dercums disease & 2 \\
\hline Cheilitis & 2 \\
\hline Postherpetic neuralgia & 2 \\
\hline Xeroderma & 2 \\
\hline Abrasions & 1 \\
\hline Atrophoderma & 1 \\
\hline Elastosis & 1 \\
\hline Morphoea & 1 \\
\hline Leg ulcer & 1 \\
\hline Lipodystrophy & 1 \\
\hline Lipomata & 1 \\
\hline Pagets disease & 1 \\
\hline Pearly penile papules & 1 \\
\hline Port wine stain & 1 \\
\hline Purpura & 1 \\
\hline Reiters syndrome & 1 \\
\hline Tound dehiscence & 1 \\
\hline $\mathbf{7 7}$ \\
\hline
\end{tabular}

Table 4: Miscellaneous Skin Disorders.

\section{Discussion}

We discovered that when considered together, infections and infestations were the commonest dermatoses $(30.8 \%)$ in this study. The study in Ghana by Doe et al in 2000 also noted a high prevalence of infections (46.3\%) [9] similar to findings by Husain, Atraide, Fekete and Onayemi [5,6,10,11]. However recent studies by Ogunbiyi, Ukonu et al recorded a higher prevalence of eczematous disorders [3,7]. The higher prevalence of infectious disorders may be due to poor environmental hygiene occurring among predominantly rural dwellers with low socio-economic status and low level of education as seen among our patients. Fungal skin disorders were the commonest form of infective skin disorder $(46.9 \%$ of all infective causes and $14.4 \%$ of the total).

Eczematous disorders ranked second in this study, with non-specific chronic dermatitis being the commonest in this group (47.1\%) followed closely by atopic dermatitis (14.4\%) and seborrheic dermatitis
(12.6\%). Chronic dermatitis seen in our patients may have arisen from the effect of treatment which modified the appearance of these dermatoses. In a prospective study by Ukonu, et al., in Benin, they recorded a prevalence of $15.3 \%$ for non-specific chronic dermatitis while contact dermatitis ranked highest for eczematous disorders (35.4\%) [7]. The study in Port Harcourt recorded atopic dermatitis as the commonest form of eczematous disorders [6]. There was also an increase in the prevalence of contact dermatitis in Ibadan and Kaduna [3,5].

Acne vulgaris was the commonest pilosebaceous disorder ( $94.2 \%$ of pilosebaceous disorders); similar to findings from other studies [4-7]. Most of these patients were secondary and university undergraduates.

Papular urticaria was the commonest urticarial lesion noted. This occurred in children and teenagers. It related to hypersensitivity to bites from insects. Patients presented with itchy papules, wheals with excoriations and sometimes with secondary bacterial colonization. A number presented with postinflammatory hyperpigmented macules and papules.

Vitiligo, albinism and post-inflammatory hypopigmentation were the commonest pigmentary disorders noted in this study. This is similar to previous studies conducted in Africa $[4,7,12]$. Some of the patients with vitiligo were erroneously labeled as Hansen's disease by primary care physicians and referred to the leprosy treatment centre in the state before being properly evaluated and referred to the skin clinic.

Papulosquamous disorders were also on the increase. The highest numbers were pityriasis rosea, lichen planus and psoriasis. These disorders reduce the overall quality of life due to the discomfort and unsightly cosmetic appearance they give to the patient.

Pruritic papular eruption (PPE) was the commonest dermatoses seen in those with HIV/AIDS (occurring in $21.2 \%$ of all patients with HIV), followed by herpes zoster and Kaposi sarcoma. Similar studies in Port Harcourt and Kaduna, noted a higher prevalence of PPE $[5,6]$. Seborrheic dermatitis was the most prevalent in the study by Nnoruka [4]. The patients with PPE who had itchy papules on the extremities resorted to the use of hydroquinone or steroid based creams for treatment with subsequent development of post-inflammatory hyperpigmented macules and papules.

Cutaneous malignancies i.e. basal cell carcinoma, squamous cell carcinoma, malignant melanoma and basal cell epithelioma seen here occurred in those with albinism. The diagnosis was confirmed with the aid of 


\section{Epidemiology international journal}

histopathology. These patients were managed in consonance with the plastic surgeons. This finding highlights the need for patients with albinism to be properly educated on the dangers of skin exposure to the damaging effects of ultra-violet rays [13].

\section{Conclusion}

This review shows that infective skin disorders ranked highest in prevalence in contrast to more recent findings in other geopolitical zones, where eczematous disorders were the most prevalent. This information is important, as it would assist in proper health planning for management of dermatological conditions.

\section{References}

1. King S (2004) Growing awareness of skin diseases starts a flurry of initiatives. Bulletin of World Health Organisation.

2. Rook A, Savin JA, Wilkinson DS (1987) The prevalence, incidence and ecology of diseases of skin, In Rook A, Wilkinson DS, Ebling FJ, Champion $\mathrm{RH}$, Burton JL, editors, Text book of Dermatology. Oxford University Press, Mumbai, 39-53.

3. Ogunbiyi A0, Daramola O0M, Alese 00 (2004) Prevalence of skin diseases in Ibadan, Nigeria. Int J Dermatol 43(1): 31-36.

4. Nnoruka EN (2004) Skin diseases in South-East Nigeria. A current perspective. Int J Dermatol 44(1): 29-33.

5. Husain Y (2007) Change in pattern of skin disease in Kaduna, North- central Nigeria. Int J Dermatol 46(9): 936-946.
6. Atraide AA, Akpa MR, George IO. Pattern of skin disorders in a Nigerian tertiary hospital. J Public Health and Epid 3(4): 177-181.

7. Ukonu BA, Eze EU (2012) Pattern of skin diseases at University of Benin Teaching Hospital, Benin-city, Edo state, South-South, Nigeria: A 12 month prospective study. Global J Health Sci 4(3): 148-157.

8. Official gazette (FGP.71/52007/2500 (0224). Legal notice on publication of the details of the breakdown of the National and State provisional totals. 2006 census. Federal republic of Nigeria. 2006 population census Abuja 2007: 1-10

9. Doe PT, Asiedu A, Acheampong JW, Rowland Payne CM (2001) Skin diseases in Ghana and the UK. Int J Dermatol 40(5): 323-326.

10. Fekete E (1978) The pattern of diseases of the skin in the Nigerian Guinea Savannah. Int J Dermatol 17(4): 331-338.

11. Onayemi O, Isezuo SA, Njoku CH (2005) Prevalence of different skin conditions in an outpatients setting in North-Western Nigeria. Int J Dermatol 44(1): 7 11.

12. Onunu AN, Kubeyinje PE (2003) Vitiligo in the Nigerian African: A study of 351 patients in Benin City Nigeria. Int J Dermatol 42(10): 800-802.

13. Okoro AN (2006) Albinism in Nigeria: A clinical and social study. Br J Dermatol 92(5): 485-492. 